\title{
DAMPAK METODE GALLERY WALK DALAM PEMBELAJARAN BAHASA JEPANG DI JURUSAN PARIWISATA POLITEKNIK NEGERI BALI
}

\author{
Kanah¹, W. Dyah ${ }^{2}$, L. Darlina ${ }^{3}$, Solihin ${ }^{4}$ \\ 1234Jurusan Pariwisata, Politeknik Negeri Bali, Badung \\ e-mail:kanah@pnb.ac.id, dyah@pnb.ac.id, darlina@pnb.ac.id, solihinmoelyadi@gmail.com
}

\begin{abstract}
Abstrak
Penelitian ini bertujuan untuk mendeskripsikan dampak penggunaan metode Gallery Walk dalam Pembelajaran bahasa Jepang di Jurusan Pariwisata, Poiteknik Negeri Bali. Penelitian ini bermanfaat untuk dijadikan referansi untuk semua pengajar dalam mempelajari metode Gallery Walk dan mengimplementasikannya kedalam kelas. Demikian juga untuk pembaca yang ingin mengetahui mengenai dampak penggunaan metode Gallery Walk dalam pembelajaran bahasa Jepang. Sumber data penelitian ini adalah mahasiswa Jurusan Pariwisata tahun pertama semester dua yang telah menerima pembelajaran bahasa Jepang dengan menggunakan metode Gallery Walk. Data penelitian ini berupa hasil kuesioner yang telah dibagikan kepada sampel untuk kemudian dijabarkan agar dapat diketahui dampak penggunaan metode Gallery Walk dalam Pembelajaran bahasa Jepang di Jurusan Pariwisata, Poiteknik Negeri Bali. Hasil penelitian ini menunjukkan bahwa pengalihan metode pembelajaran bahasa Jepang dari metode ceramah ke metode Gallery Walk membawa perubahan yang signifikan terhadap minat belajar mahasiswa. Begitu pula dengan meningkatnya kreatifitas, keberanian untuk berbicara di depan kelas, dan kerjasama dalam kelompok.
\end{abstract}

Kata kunci: gallery walk, metode pembelajaran, bahasa Jepang

\section{要指}

本研究の目的は、バリ国立ポリテクニックの観光学科での日本語学習におけるギャラリー ウォーク 方法の使用の影響を説明することである。調査は、すべての教師がギャラリー ウオーク法を研究し、 それを教室で実践するための参考資料として役立つ。同様に、日本語学習においてギャラリー ウオー ク 方法を使用することの影響について知りたい読者のためにもできる。データソースは、観光学科の 2 学期の 1 年生で、ギャラリーウオーク方法で日本語を学習した学生であった。調査のデータは、バ リ国立ポリテクニックの観光学科の日本語学習でギャラリー ウオーク 方法を使用することの影響を 知るために、後で詳しく説明するサンプルに配布されたアンケートの形式になっていた。結果は、日 本語の学習方法をスピーチ方法からギャラリーウオーク方法に移行することで、学生の学習意欲にずい ぶん大きな変化がもたらされることがわかる。同様に、創造性の向上、クラスの前で話す勇気、グ ルー プでの協力。

キーワード : 学習方法、ギャラリーウオーク、日本語

\section{Pendahuluan}

Pendidikan menjadi sangat penting manakala manusia tidak dapat memungkiri bahwa dengan perkembangan zaman di dunia pendidikan terus mengalami kemajuan sehingga banyak mengubah pola pikir pendidik, dari pola pikir yang awam dan kaku menjadi lebih modern. Hal tersebut sangat berpengaruh dalam kemajuan pendidikan di Indonesia. Hanya saja, seiring dengan kemajuan pendidikan terkadang konsep atau pengertian tersebut mungkin menjadi kabur. Dewey (dalam Marteja, 2020) menjelaskan bahwa intisari atau hakikat pendidikan adalah upaya sadar dari suatu masyarakat dan pemerintah suatu negara 
untuk menjamin kelangsungan hidup dan kehidupan generasi penerusnya, selaku warga masyarakat, bangsa dan negara, secara berguna dan bermakna serta mampu mengantisipasi hari depan mereka yang senantiasa berubah dan selalu terkait dengan konteks dinamika budaya, bangsa, negara dan hubungan internasionalnya. Dengan demikian, masyarakat perlu dibekali dengan ilmu pengetahuan yang mumpuni baik itu berkaitan dengan aspek kognitif, psikomotor maupun spiritual untuk menghadapi berbagai tantangan yang ada dalam era globalisasi ini Nur (2012). Pengajaran dalam dunia pendidikan merupakan sebuah proses yang melahirkan interaksi yang berisi berbagai model dan metode pembelajaran yang bertujuan untuk meningkatkan minat belajar peserta didik agar hasil belajarnya dapat maksimal. Menurut Kusyairy (2014), keberhasilan dalam proses belajar ditentukan oleh kesanggupan belajar peserta didik. Pada proses belajar terdapat banyak faktor yang menunjang, yakni kebiasaan belajar, konsep diri, motivasi, sikap, dan minat. Menurut Marno, dkk (dalam Setiawan dan Nurasiah, 2018), dalam kegiatan pembelajaran, terdapat dua kegiatan yang sinergis, yakni Pendidik mengajar dan Peserta didik belajar. Pendidik mengajarkan bagaimana Peserta didik harus belajar. Sementara Peserta didik belajar bagaimana seharusnya belajar melalui berbagai pengalaman belajar hingga terjadi perubahan dalam dirinya dari aspek kognitif, psikomotor dan atau afektif. Karena itu Pendidik harus merancang kegiatan pembelajaran yang memungkinkan Peserta didik melakukan kegiatan belajar secara aktif, baik fisik maupun mental. Peserta didik akan belajar secara aktif kalau rancangan pembelajaran yang disusun Pendidik mengharuskan Peserta didik, baik secara sukarela maupun terpaksa. Dengan demikian ada korelasi signifikan antara kegiatan mengajar Pendidik dan kegiatan belajar Peserta didik. Mengaktifkan kegiatan belajar Peserta didik berarti menuntut kreativitas dan kemampuan Pendidik dalam merancang dan melaksanakan kegiatan pembelajaran.

Dewasa ini, terjadi perubahan paradigma pembelajaran, yaitu peserta didik dituntut untuk lebih aktif, kreatif dan inovatif selama proses pembelajaran. Ini berarti peserta didik diposisikan sebagai subjek belajar dan Pendidik sebagi fasilitator. Adanya perubahan paradigma proses pembelajaran yang berpusat pada peserta didik diharapkan mendorong peserta didik untuk terlibat lebih aktif dalam membangun pengetahuan, sikap dan keterampilannya (Chatif, 2012). Metode yang monoton merupakan salah satu faktor yang memengaruhi kurangnya minat peserta didik dalam menerima pelajaran. Seperti dalam mata kuliah bahasa Jepang yang merupakan salah satu mata kuliah yang diajarkan pada jurusan Pariwisata, Politeknik Negeri Bali. Bahasa Jepang tidak begitu menarik minat sebagian besar mahasiswa, ditambah lagi dalam pembelajaran bahasa Jepang, metode ceramah masih dipertahankan sehingga sesuai dengan fenomena yang terjadi, mahasiswa yang sedang belajar bahasa Jepang semakin tidak memiliki minat dalam belajar.

Untuk menciptakan proses belajar-mengajar yang baik, diperlukan model pembelajaran yang mampu menciptakan suasana yang menyenangkan yang dapat membangkitkan minat Peserta didik dalam belajar. Salah satunya adalah model pembelajaran dengan metode Gallery Walk. Inti dari pembelajaran adalah pembelajaran Peserta didik secara berkelompok. Melalui kelompok, mereka akan membentuk diskusi, mengerjakan tugas bersama, saling membantu dan mendukung ketika diberikan masalah yang harus didiskusikan. Percobaan penggunaan metode Gallery Walk dalam pembelajaran bahasa Jepang telah dilakukan di enam kelas dari 12 kelas yang ada di jurusan Pariwisata, Politeknik Negeri Bali yang dijadikan objek penelitian tindakan kelas. Percobaan penggunaan metode Gallery Walk ini dilakukan sebelum pandemi covid-19 muncul dan perkuliahan daring dilakukan. Hasil dari percobaan tersebut memperlihatkan bahwa terjadi perubahan minat pada mahasiswa yang melakukan pembelajaran dengan menggunakan metode Gallery Walk dari yang sebelumnya tidak tertarik menjadi lebih bersemangat dan tertarik dalam mengikuti pembelajaran tersebut dibandingkan dengan kelas yang belum melakukan pembelajaran dengan metode Gallery Walk. Selanjutnya, berdasarkan hasil yang telah didapat tersebut, 
dimana pengunaan metode Gallery Walk yang menggantikan metode ceramah dapat mengubah minat mahasiswa menjadi lebih baik, maka metode Gallery Walk lalu diimplementasikan pada setiap kelas mata kuliah bahasa Jepang yang diberikan untuk mahasiswa tahun pertama yang ada di jurusan Pariwisata.

Gallery Walk sebagai salah satu metode pembelajaran bertujuan untuk mengatasi kendala-kendala pembelajaran, dan untuk meningkatkan motivasi serta keaktifan peserta didik dalam proses belajar mengajar. Saiful (dalam Manik, 2019). Selain itu, Gallery Walk adalah suatu model pembelajaran yang mampu meningkatkan kemampuan peserta didik untuk menemukan pengetahuan baru dan dapat mempermudah daya ingat karena sesuatu yang di temukan itu dilihat secara langsung. Metode ini baik digunakan untuk membangun kerjasama (cooperative learning). Gallery Walk juga dapat memotivasi keaktifan peserta didik dalam proses belajar, sebab bila sesuatu yang baru ditemukan berbeda antara satu dengan yang lainnya, maka dapat mengoreksi antar-Peserta didik baik kelompok maupun antar Peserta didik itu sendiri.

Gallery Walk memberikan kesempatan kepada peserta didik untuk membuat suatu karya dan melihat hasil karya kelompok yang lain sehingga dapat saling mengisi kekurangannya itu. Jadi, Metode Pembelajaran Gallery Walk merupakan model pembelajaran yang dapat diterapkan untuk semua mata pelajaran dan tingkatan kelas serta memberikan kesempatan kepada masing-masing anggota kelompok untuk menuangkan ide, serta gagasannya untuk menyempurnakan hasil kerja kelompoknya, serta mendengarkan saran maupun kritik dari anggota kelompok lainnya, dengan peran-peran khusus tiap anggota tim atau kelompok yang telah dibagi untuk bertanggung jawab atas tugas yang diberikan oleh ketua tim atau kelompok.

Ada beberapa penelitian mengenai penggunaan metode Gallery Walk dalam menyikapi permasalahan kurangnya minat belajar Peserta didik. Salah satunya adalah penelitian yang dilakukan oleh Setiawan dan Nurasiah (2018) dalam penelitian yang berjudul "Galery Walk Dalam Aktivitas Belajar: Penelitian Tindakan Kelas Di Madrasah Ibtidaiyah". Hasil penelitian menunjukkan bahwa ada pengaruh dari penerapan metode Gallery Walk terhadap meningkatnya aktivitas belajar siswa dilihat dari persentase pengukuran aktivitas belajar siswa pra sikus sebesar $28,07 \%$ dengan kriteria kurang. Siklus 1 sebesar $62,6 \%$ dengan kriteria baik, sedangkan siklus 2 sebesar 83,3\% dengan kriteria sangat baik. Berdasarkan temuan-temuan tersebut dapat diketahui bahwa penerapan Gallery Walk dapat meningkatkan aktivitas belajar siswa pada mata pelajaran SBK pokok bahasan jenis motif hias. Selanjutnya, Marteja (2020) dengan judul penelitian "Model Pembelajaran Gallery Walk Pada Mata Pelajaran Jurnal Khusus Perusahaan Dagang Di Sman 1 Rejang Lebong". Hasil penelitian menunjukkan bahwa Hasil penelitian menyatakan bahwa terjadi peningkatan siswa yang aktif dari siklus 1, siklus 2 dan siklus 3. Peningkatan rata-rata hasil belajar diikuti dengan ketuntasan belajar. Siklus I mencapai rata-rata 59,16 dan siswa tuntas belajar 45,83\%, Siklus II mencapai rata-rata 67,08 dan siswa tuntas belajar $54,16 \%$, Siklus III mencapai rata-rata 85,41 dan siswa tuntas belajar $100 \%$. Model pembelajaran Gallery Walk dapat meningkatkan aktivitas belajar lebih semarak baik klasikal, kelompok maupun individu.

Penelitian ini lebih memfokuskan mengenai Dampak dari implementasi Metode Gallery Walk dalam Pembelajaran Bahasa Jepang di semua kelas yang ada pada Jurusan Pariwisata Politeknik Negeri Bali.

\section{Metode}

Pendekatan yang digunakan dalam penelitian ini adalah pendekatan kuantitatif dan deskriptif kualitatif. Dikatakan kuantitatif, karena penelitian ini akan mencari tingkat persentase hasil pembelajaran bahasa Jepang dengan menggunakan metode Gallery Walk. Dikatakan deskriptif kualitatif karena penelitian ini juga mengumpulkan data yang berasal dari persentasi, 
catatan lapangan, dokumen pribadi, catatan, memo, dan dokumen resmi lainnya sehingga yang menjadi tujuan dalam penelitian kualitatif ini, yaitu ingin menggambarkan realita empirik dibalik fenomena secara mendalam, rinci, dan tuntas. Dikatakan deskriptif karena penelitian ini berusaha menjelaskan dampak penggunaan metode Gallery Walk dalam pembelajaran bahasa Jepang di jurusan Pariwisata, Politeknik Negeri Bali.

Populasi dalam penelitian ini adalah semua mahasiswa jurusan Pariwisata Politeknik Negeri Bali yang sedang mempelajari bahasa Jepang dengan metode Gallery Walk, sedangkan Sampel dalam penelitian ini adalah mahasiswa Jurusan Pariwisata tahun pertama semester dua yang diambil dengan menggunakan rumus slovin menurut Sugiyono (2017), yaitu:

$$
n=\frac{N}{\left(N \cdot d^{2}\right)+1}
$$

Keterangan:

$$
\begin{aligned}
& \mathrm{n}=\text { jumlah sampel } \\
& \mathrm{N}=\text { jumlah populasi } \\
& \mathrm{d}=\text { galat/kesalahan pengambilan sampel }
\end{aligned}
$$

Dari 12 kelas di jurusan Pariwisata yang sedang belajar Bahasa Jepang, jumlah mahasiswa sebanyak 392 mahasiswa. Dengan galat pengambilan sampel sebesar $10 \%$ atau 0.1 , maka diperoleh jumlah sampel:

$$
n=\frac{392}{\left(392 .(0.1)^{2}\right)+1}=79,6747967 \approx 80
$$

Maka jumlah sampel yang diambil dalam penelitian ini sebanyak 80 mahasiswa jurusan Pariwisata.

Setelah mengambil sampel dengan rumus slovin, terdapat 80 mahasiswa dari total 392 mahasiswa yang menjadi sampel. Untuk menentukan jumlah mahasiswa yang akan diambil tiap kelas, maka teknik pengambilan sampel selanjutnya yang digunakan adalah bentuk purposive sampling. Purposive sampling, merupakan teknik pengambilan sampel yang dilakukan dengan cara sengaja. Maksudnya sampel dipilih dengan sengaja agar kriteria sampel yang diperoleh benar-benar sesuai dengan penelitian yang dilakukan, maka diambil masing-masing kurang lebih 7 mahasiswa yang memenuhi standar kehadiran $100 \%$, sehingga mahasiswa yang dijadikan sebagai sumber data bisa didapat secara valid dan lengkap.

Tabel 1. Penentuan Jumlah Sampel Penelitian

\begin{tabular}{ccccc}
\hline Status & Jumlah Sampel & Kelas & $\begin{array}{c}\text { Jumlah } \\
\text { Mahasiswa }\end{array}$ & $\begin{array}{c}\text { Jumlah } \\
\text { Sampel }\end{array}$ \\
\hline \multirow{5}{*}{ Sampel } & A MBP & 34 & 7 \\
& B MBP & 34 & 7 \\
& C MBP & 34 & 7 \\
& D MBP & 33 & 7 \\
& E MBP & 33 & 7 \\
& A Hotel & 32 & 6 \\
& B Hotel & 32 & 6 \\
& C Hotel & 33 & 7 \\
& D Hotel & 32 & 6 \\
& E Hotel & 33 & 7 \\
& A UPW & 32 & 7 \\
& B UPW & 30 & 6 \\
\hline
\end{tabular}

Menurut Sugiyono (2018), pengumpulan data diperoleh dari observasi, wawancara, dokumentasi dan triangulasi. Penelitian ini menggunakan teknik observasi, wawancara, dan 
dokumentasi. Teknik pengumpulan data tersebut dijabarkan sebagai berikut: (1) Observasi. Menurut Syaodih (dalam Satori dan Komariah, 2013) mengatakan bahwa, observasi atau pengamatan merupakan suatu teknik atau cara mengumpulkan data dengan jalan mengadakan pengamatan terhadap kegiatan yang sedang berlangsung. Penelitian ini menggunakan teknik observasi partisipatif. Menurut Sugiyono (2017), observasi partisipatif merupakan pengamatan dimana peneliti terlibat dalam kegiatan sehari-hari orang yang sedang diamati atau yang digunakan sebagai sumber data penelitian. Dengan observasi partisipan ini, maka data yang diperoleh lebih tajam, dan sampai mengetahui pada tingkat makna dari setiap perilaku yang nampak.

Dalam pengumpulan data penelitian ini, penulis terlibat sepenuhnya terhadap sumber data, dalam hal ini penulis berposisi sebagai pengajar dan sumber data adalah mahasiswa yang sedang belajar bahasa Jepang; (2) Wawancara. Menurut Beg (dalam Satori dan Komariah 2013), wawancara sebagai suatu percakapan dengan suatu tujuan, khususnya tujuan untuk mengumpulkan informasi. Wawancara digunakan sebagai teknik pengumpulan data jika peneliti akan melakukan studi pendahuluan untuk menemukan permasalahan yang harus diteliti, dan peneliti juga ingin mengetahui hal-hal dari responden yang lebih mendalam.

Dalam penelitian ini, penulis mengajukan pertanyaan terstruktur karena menggunakan pedoman wawancara yang disusun secara sistematis dan lengkap untuk mengumpulkan data yang dicari. Wawancara dalam penelitian ini dilakukan pada mahasiswa di Jurusan Pariwisata yang telah menerima metode Gallery Walk dalam pembelajaran bahasa Jepang. Setelah melakukan wawancara secara mendalam, maka diharapkan semua sumber data yang telah didapat melalui wawancara menjadi lebih lengkap dan tajam; (3) Dokumentasi. Menurut Sugiyono (2018), dokumentasi merupakan catatan peristiwa pada waktu yang lalu, dan dapat berbentuk tulisan, gambar, maupun karya-karya monumental dari seseorang. Dalam penelitian ini, dokumentasi menggunakan data berupa catatan, transkrip, buku, surat kabar, majalah, dan sebagainya yang berhubungan dengan masalah penelitian. dokumen yang dimaksud adalah hasil dari kuesioner yang telah diberikan kepada mahasiswa, dan hasil pembelajaran bahasa Jepang yang telah menggunakan metode Gallery Walk.

Uji coba metode Gallery Walk dilakukan sebelum pandemi Covid-19, sehingga pembelajaran dilakukan dengan luring, sedangkan implementasi secara keseluruhan terhadap kelas dilakukan sebelum pandemi yang dilakukan secara luring hingga sekarang dimasa pandemi yang dilakukan secara daring. Perbedaannya sangat jelas terlihat dari manajemen waktu. Oleh karena itu, penggunaan metode Gallery Walk dalam kelas daring harus disesuaikan, khususnya dalam manajemen waktu.

\section{Hasil dan Pembahasan}

Dalam kuesioner yang disebarkan kepada 80 mahasiswa yang telah dipilih untuk menjadi sampel, terdapat sepuluh pertanyaan yang berkaitan dengan pembelajaran bahasa Jepang dengan metode Gallery Walk yang telah diimplementasikan pada setiap kelas yang sedang belajar mata kuliah bahasa Jepang di jurusan Pariwisata, Politeknik Negeri Bali. Kesepuluh pertanyaan tersebut memiliki masing-masing skala penilaian, yaitu sangat setuju (SS), setuju (S), Cukup (C), tidak setuju (TS), dan sangat tidak setuju (STS). Mahasiswa yang menjadi sampel lalu mengisi kuesioner tersebut sesuai dengan sumpah yang telah diucapkan kepada Tim peneliti, yaitu mengisi kuesioner dengan jujur dan tidak memberikan jawaban yang tidak benar.

Hasil kuesioner yang telah didapatkan dari 80 sampel tersebut kemudian dicari persentasenya. Selanjutnya, hasil persentase tiap skala dari tiap poin dijadikan bahan untuk mendeskripsikan dampak dari implementasi metode Gallery Walk dalam pembelajaran bahasa Jepang. 
Berikut hasil tanggapan mahasiswa terhadap kuesioner pasca-pembelajaran menggunakan metode Gallery Walk, yaitu.

Tabel 2. Rerata Tanggapan Responden Pasca-Gallery Walk

\begin{tabular}{|c|c|c|c|c|c|c|c|}
\hline No. & Pernyataan & SS & $S$ & C & TS & STS & $\begin{array}{c}\text { Jumlah } \\
\text { Responden }\end{array}$ \\
\hline 1 & $\begin{array}{l}\text { Metode baru yang } \\
\text { diberikan lebih baik } \\
\text { dibandingkan metode } \\
\text { yang sebelumnya. }\end{array}$ & 64 & 12 & 4 & 0 & 0 & \\
\hline 2 & $\begin{array}{l}\text { Saya lebih menyukai } \\
\text { pembelajaran sekarang } \\
\text { dibandingkan semester } \\
\text { sebelumnya karena } \\
\text { lebih menyenangkan. }\end{array}$ & 78 & 2 & 0 & 0 & 0 & \\
\hline 3 & $\begin{array}{l}\text { Pembelajaran sekarang } \\
\text { masih membosankan } \\
\text { seperti sebelumnya. }\end{array}$ & 0 & 0 & 0 & 34 & 46 & \\
\hline 4 & $\begin{array}{l}\text { Saya dapat } \\
\text { meningkatkan } \\
\text { konsentrasi belajar } \\
\text { kosakata bahasa } \\
\text { Jepang. }\end{array}$ & 9 & 38 & 27 & 6 & 0 & \\
\hline 5 & $\begin{array}{l}\text { Saya lebih aktif dalam } \\
\text { kelas. }\end{array}$ & 16 & 50 & 12 & 1 & 1 & 80 \\
\hline 6 & $\begin{array}{l}\text { Saya masih belum } \\
\text { berani berbicara di } \\
\text { depan kelas. }\end{array}$ & 0 & 2 & 9 & 51 & 18 & \\
\hline 7 & $\begin{array}{l}\text { Saya bisa berkreasi } \\
\text { dan memunculkan ide } \\
\text { yang bagus saat } \\
\text { mendapatkan tugas. }\end{array}$ & 18 & 48 & 13 & 1 & 0 & \\
\hline 8 & $\begin{array}{l}\text { Semua teman } \\
\text { kelompok saya aktif } \\
\text { dan menyumbangkan } \\
\text { ide saat diberikan } \\
\text { tugas. }\end{array}$ & 69 & 4 & 3 & 4 & 0 & \\
\hline 9 & $\begin{array}{l}\text { Pembelajaran sekarang } \\
\text { membuat saya menjadi } \\
\text { kurang aktif karena } \\
\text { teman-teman saya } \\
\text { yang lain sudah aktif } \\
\text { dan kreatif. }\end{array}$ & 0 & 2 & 0 & 8 & 70 & \\
\hline
\end{tabular}




\begin{tabular}{lllllll} 
& $\begin{array}{l}\text { Saya mampu } \\
\text { bekerjasama dalam }\end{array}$ \\
kelompok. & 63 & 16 & 1 & 0 & 0 \\
\hline
\end{tabular}

Berdasarkan tabel diatas, dapat dibuatkan persentase untuk setiap poin pernyataan yang ada dalam kuesioner. Berikut penjelasan tiap poin.

\section{a. Metode Gallery Walk Lebih Baik}

Poin pertama berisi mengenai pernyataan bahwa "Metode baru yang diberikan lebih baik dibandingkan metode yang sebelumnya". Berikut tabel persentasi skalanya:

Tabel 3. Persentase poin 1

\begin{tabular}{ccc}
\hline Skala & Jumlah & $\begin{array}{c}\text { Persentase } \\
(\%)\end{array}$ \\
\hline SS & 64 & 80 \\
S & 12 & 15 \\
C & 4 & 5 \\
TS & 0 & 0 \\
STS & 0 & 0 \\
\hline
\end{tabular}

Menurut tabel di atas, dapat dideskripsikan bahwa sebanyak $80 \%$ mahasiswa sangat setuju bahwa metode yang mereka dapatkan sekarang lebih baik dibanding metode sebelumnya, sedangkan $15 \%$ mengatakan setuju, dan 5\% mengatakan cukup setuju. Dilain pihak, tidak ada mahasiswa yang memberikan jawaban tidak setuju dan sangat tidak setuju dengan poin pertama.

Berdasarkan uraian tersebut di atas, dapat disimpulkan bahwa sebanyak $100 \%$ mahasiswa lebih memilih pembelajaran dengan menggunakan metode Gallery Walk karena metode tersebut lebih baik dibandingkan metode ceramah. Dalam pembelajaran menggunakan metode Gallery Walk, mahasiswa tidak hanya menjadi pendengar lagi, tetapi menjadi pusat dalam pembelajaran.

\section{b. Metode Gallery Walk Lebih Menyenangkan}

Poin kedua berisi mengenai pernyataan bahwa "Saya lebih menyukai pembelajaran sekarang dibandingkan semester sebelumnya karena lebih menyenangkan". Berikut tabel persentasi skalanya:

Tabel 4. Persentase poin 2

\begin{tabular}{ccc}
\hline Skala & Jumlah & $\begin{array}{c}\text { Persentase } \\
(\%)\end{array}$ \\
SS & 0 & 97,5 \\
S & 0 & 2,5 \\
C & 0 & 0 \\
TS & 34 & 0 \\
STS & 46 & 0 \\
\hline
\end{tabular}

Menurut tabel di atas, dapat dideskripsikan bahwa sebanyak 97,5\% mahasiswa sangat setuju bahwa penggunaan metode Gallery Walk dalam kelas Bahasa Jepang sangat menyenangkan, sedangkan 2,5\% mengatakan setuju. Dalam pembelajaran bahasa Jepang 
dengan metode Gallery Walk di jurusan Pariwisata, dosen membagi mahasiswa dalam beberapa kelompok dengan berbagai cara agar terkesan tidak memilih secara subjektif. Salah satunya adalah membagi kelompok sesuai dengan hasil melakukan permainan pada saat ice breaking.

Berdasarkan uraian tersebut di atas, dapat disimpulkan bahwa sebanyak $100 \%$ mahasiswa lebih memilih pembelajaran dengan menggunakan metode Gallery Walk karena metode tersebut lebih menyenangkan. Dalam pembelajaran menggunakan metode Gallery Walk, mahasiswa tidak akan menjadi bosan mendengarkan teori saja, tetapi suasana dalam kelas dapat menjadi ramai dan menyenangkan.

\section{c. Metode Gallery Walk Tidak Membosankan}

Poin tiga berisi mengenai pernyataan bahwa "Pembelajaran sekarang masih membosankan seperti sebelumnya". Berikut tabel persentasi skalanya.

Tabel 5. Persentase poin 3

\begin{tabular}{ccc}
\hline Skala & Jumlah & $\begin{array}{c}\text { Persentase } \\
(\%)\end{array}$ \\
SS & 78 & 0 \\
S & 2 & 0 \\
C & 0 & 0 \\
TS & 0 & 42,5 \\
STS & 0 & 57,5 \\
\hline
\end{tabular}

Sesuai dengan tabel di atas, dapat dideskripsikan bahwa sebanyak $57,5 \%$ mahasiswa sangat tidak setuju dan $42,5 \%$ tidak setuju dengan pernyataan poin ketiga bahwa pembelajaran Gallery Walk membosankan. Dalam pembelajaran bahasa Jepang dengan metode Gallery Walk di jurusan Pariwisata, dosen berusaha agar mahasiswa bisa tetap fokus selama pembelajaran dalam kelas berlangsung. Dalam Gallery Walk, tiap kelompok diberikan masing-masing topik yang akan mereka bahas dan presentasikan dengan membuat pameran dan mereka akan berjalan berkeliling untuk melihat presentasi kelompok lain dan mengajukan pertanyaan jika mereka mempunyai pertanyaan untuk kelompok yang lain. Agar tidak monoton dan meminimalisir keramaian yang tidak perlu, maka dosen pun biasanya mengubah cara permainan dengan melakukan pameran tanpa berjalan, tetapi presentasi kelompok yang akan berkeliling menuju tiap kelompok lain yang akan menunggu giliran.

Berdasarkan uraian tersebut di atas, dapat disimpulkan bahwa sebanyak 100\% mahasiswa mengatakan bahwa metode Gallery Walk tidak membosankan. Selama pembelajaran, mahasiswa menjadi aktif dan tidak ada yang tinggal mendengarkan, karena semua mahasiswa mendapat giliran untuk berbicara dan mengemukakan pendapat.

\section{d. Meningkatkan Konsentrasi}

Poin keempat berisi mengenai pernyataan bahwa "Saya dapat meningkatkan konsentrasi belajar kosakata bahasa Jepang”. Berikut tabel persentasi skalanya.

Tabel 6. Persentase poin 4

\begin{tabular}{ccc}
\hline Skala & Jumlah & $\begin{array}{c}\text { Persentase } \\
(\%)\end{array}$ \\
SS & 9 & 11,25 \\
S & 38 & 47,5
\end{tabular}




\begin{tabular}{ccc}
\hline C & 27 & 33,75 \\
TS & 6 & 7,5 \\
STS & 0 & 0 \\
\hline
\end{tabular}

Menurut tabel di atas, dapat dideskripsikan bahwa sebanyak 11,25\% mahasiswa sangat setuju, sebanyak $47,5 \%$ setuju, dan $33,75 \%$ cukup setuju bahwa implementasi penggunaan metode Gallery Walk dalam pembelajaran Bahasa Jepang dapat meningkatkan konsentrasi mereka dalam belajar kosakata bahasa Jepang, sedangkan 7,5\% mengatakan tidak setuju. Pembelajaran bahasa seara umum tidak terlepas dari belajar mengenai kosakata, karena kosakata merupakan hal yang wajib untuk dipelajari dalam belajar bahasa. Seperti dalam kelas bahasa Jepang, kosakata bahasa Jepang memiliki banyak kata namun penggunaannya harus sesuai dengan kondisi dan situasi, serta melihat lawan bicara dan orang ketiga. Cara belajar kosakata sangat beragam, salah satunya adalah melalui metode Gallery Walk. Pada saat pembelajaran bahasa Jepang di jurusan Pariwisata, Politeknik Negeri Bali, dosen melakukan ice breaking sebelum memulai atau pada saat melihat kondisi kelas mulai jenuh. Ice breaking dapat berupa permainan-permainan yang menyenangkan yang dapat membuat mahasiswa melatih konsentrasi dalam pembelajaran kosakata.

Berdasarkan uraian tersebut di atas, dapat disimpulkan bahwa sebanyak $92,5 \%$ mahasiswa dapat berkonsentrasi dalam pembelajaran kosakata bahasa Jepang dengan menggunakan metode Gallery Walk, sedangkan sisanya masih belum bisa berkonsentrasi. Berdasarkan hasil interview, hal ini disebabkan ada beberapa tipe mahasiswa yang memang membutuhkan suasana yang tenang pada saat pembelajaran sehingga mereka urang bisa berkonsentrasi pada saat suasana ramai. Di lain pihak, sebagian besar mengatakan bahwa kondisi yang ramai dan menyenangkan dalam kelas membuat mereka dapat menghapal kosakata dengan cepat. Untuk itu, maka dosen harus memikirkan cara agar semua mahasiswa dapat berkonsentrasi dalam pembelajaran kosakata. Utnuk mengatasi hal tersebut, maka dosen setidaknya memperkenalkan mahasiswa yang menyukai ketenangan dengan hal yang ramai dan membiasakan mereka untuk bekerjasama dengan mahasiswa yang menyukai keramaian, agar mereka bisa lebih percaya diri dan dapat merubah pola pikir mereka sedikit demi sedikit.

\section{e. Lebih Aktif}

Poin kelima berisi mengenai pernyataan bahwa "Saya lebih aktif dalam kelas". Berikut tabel persentasi skalanya.

Tabel 7. Persentase poin 5

\begin{tabular}{ccc}
\hline Skala & Jumlah & $\begin{array}{c}\text { Persentase } \\
(\%)\end{array}$ \\
SS & 16 & 20 \\
S & 50 & 62,5 \\
C & 12 & 15 \\
TS & 1 & 1,25 \\
STS & 1 & 1,25 \\
\hline
\end{tabular}

Sesuai dengan persentasi tabel di atas, dapat dideskripsikan bahwa sebanyak $20 \%$ mahasiswa sangat setuju, $64,5 \%$ setuju, dan $15 \%$ cukup setuju bahwa penggunaan metode Gallery Walk dalam pembelajaran Bahasa Jepang membuat mahasiswa menjadi lebih aktif selama pembelajaran berlangsung, sedangkan sebanyak 1,25\% masing-masing mengatakan tidak setuju dan sangat tidak setuju. Metode Gallery Walk 'memaksa' 
mahasiswa untuk menjadi aktif selama pembelajaran berlangsung, karena semua mahasiswa mendapatkan giliran untuk berbicara sehingga mereka harus aktif dan menguasai topik yang telah diberikan dalam kelompok. Hal ini membuat setiap anggota tidak memiliki anggota yang tidak menguasai topik.

Berdasarkan uraian tersebut di atas, dapat disimpulkan bahwa sebanyak $97,5 \%$ mahasiswa menjadi aktif selama mengerjakan tugas dalam kelompok, sedangkan sebanyak 2,5\% merasa kurang aktif. Berdasarkan hasil interview, hal ini disebabkan ada beberapa mahasiswa yang merasa kurang percaya diri untuk aktif karena tertutupi oleh teman kelompok mereka yang lebih aktif dan pendapatnya lebih didengarkan oleh anggota yang lain. Oleh karena itu, dosen sebagai fasilitator dalam pebelajaran harus mengetahui kondisi seperti diatas untuk bisa menemukan solusi dalam rangka meredam mahasiswa yang tampil melebihi teman yang lain agar semua mendapat jatah dan rata dalam hal keaktifan. Untuk memecahkan masalah di atas, dosen menyetop dengan sopan dan memberikan pujian kepada mahasiswa yang lebih dominan tersebut pada saat diskusi sedang berlangsung dan memberikan kesempatan kepada mahasiswa lain untuk berbicara.

Poin ini memiliki hubungan dengan pernyataan nomor sembilan, yaitu "Pembelajaran sekarang membuat saya menjadi kurang aktif karena teman-teman saya yang lain sudah aktif dan kreatif". Sebanyak $97,5 \%$ mahasiswa tidak setuju bahwa mereka kurang aktif dalam pembelajaran dengan metode Gallery Walk, karena selama pembelajaran mereka dituntut untuk selalu aktif dalam kelas, sedangkan sebanyak 2,5\% mahasiswa mengatakan mereka kurang aktif dikarenakan adanya beberapa mahasiswa yang dominan.

\section{f. Memiliki Kepercayaan Diri}

Poin keenam berisi mengenai pernyataan bahwa "Saya masih belum berani berbicara di depan kelas". Berikut tabel persentasi skalanya.

Tabel 4. Persentase poin 2

\begin{tabular}{ccc}
\hline Skala & Jumlah & $\begin{array}{c}\text { Persentase } \\
(\%)\end{array}$ \\
SS & 0 & 0 \\
S & 2 & 2,5 \\
C & 9 & 11,25 \\
TS & 51 & 63,75 \\
STS & 18 & 22,5 \\
\hline
\end{tabular}

Tabel di atas memperlihatkan bahwa sebanyak $22,5 \%$ mahasiswa sangat tidak setuju, dan $63,75 \%$ tidak setuju bahwa mereka belum memiliki keberanian untuk berbicara di depan kelas, sedangkan $11,25 \%$ mengatakan cukup setuju, 2,5\% setuju, dan $0 \%$ sangat setuju bahwa mereka belum punya keberanian. Dalam pembelajaran bahasa Jepang dengan menggunakan metode Gallery Walk, mahasiswa dituntut untuk bisa mengutarakan pendapat dan ide mereka di depan kelas, sehingga mahasiswa harus memiliki keberanian untuk bisa berbicara di depan teman-temanya. Hal ini dapat mengajarkan mahasiswa untuk memiliki kepercayaan diri agar bisa tampil di depan umum. Berdasarkan uraian tersebut di atas, dapat disimpulkan bahwa sebanyak $86,25 \%$ mahasiswa mengatakan bahwa metode Gallery Walk yang mereka terima telah membuat kepercayaan diri mereka makin bertambah dan mereka pun memiliki keberanian untuk berbicara di depan orang banyak. Dilain pihak, sebanyak $13,75 \%$ mahasiswa masih belum cukup memiliki kepercayaan diri untuk berbicara di depan kelas. Hal ini dikarenakan mereka masih belum memiliki kepercayaan diri yang tinggi untuk dapat berbicara di depan umum. Salah satu alasannya adalah karena mahasiswa takut salah dan ditertawakan, bahkan ada yang takut 
mendapatkan marah dari dosen. Untuk mengatasi hal tersebut, maka dosen hendaknya memberikan motivasi kepada mahasiswa agar kepercayaan diri mereka bisa berkembang dan memberikan apresisasi terhadap hasil yang mereka berikan sekecil apapun, sehingga mahasiswa akan merasa dihargai.

\section{g. Memunculkan Kreatifitas}

Poin ketujuh berisi mengenai pernyataan bahwa "Saya bisa berkreasi dan memunculkan ide yang bagus saat mendapatkan tugas". Berikut tabel persentasi skalanya.

Tabel 4. Persentase poin 2

\begin{tabular}{ccc}
\hline Skala & Jumlah & $\begin{array}{c}\text { Persentase } \\
(\%)\end{array}$ \\
SS & 18 & 22,5 \\
S & 48 & 60 \\
C & 13 & 16,25 \\
TS & 1 & 1,25 \\
STS & 0 & 0 \\
\hline
\end{tabular}

Tabel di atas memperlihatkan bahwa sebanyak 22,5\% mahasiswa sangat setuju, $60 \%$ setuju, dan $16,25 \%$ cukup setuju bahwa mereka dapat menyaluran kreatifitas dan memmunculkan ide-ide yang kreatif dalam setiap tugas kelompok yang diberikan oleh dosen, sedangkan 1,25\% mengatakan tidak setuju. Metode Gallery Walk sangat berpengaruh terhadap kreatifitas mahasiswa karena Metode ini memberikan kesempatan kepada mahasiswa untuk membuat sebuah karya sesuai pemahaman terhadap suatu permasalahan yang didiskusikan dengan anggota kelomponya lalu diwujudkan dalam bentuk karya yang kemudian dipamerkan. Metode Gallery Walk menuntut mahasiswa untuk aktif dalam proses pembelajaran, kreatif dalam membuat suatu produk dan karya, gagasan, gambar maupun skema sesuai hal- hal apa yang ditemukan atau diperoleh pada saat diskusi kelompok untuk dipamerkan. Ide-ide yang kreatif dari mahasiswa yang muncul karena mereka diberi kebebasan untuk mempresentasikan tugas mereka dengan batasbatas yang telah disepakati dengan dosen pengampuh mata kuliah.

Berdasarkan uraian tersebut di atas, dapat disimpulkan bahwa sebanyak $98,75 \%$ mahasiswa mengatakan bahwa metode Gallery Walk memunculkan kreatifitas mereka, karena melibatkan mahasiswa secara langsung dalam kegiatan pemecahan masalah, dapat menumbuhkan motivasi belajar, menumbuhkan kreativitas siswa, mengaktifkan proses pembelajaran, menjadikan mahasiswa kreatif dan inovatif. Dilain pihak, sebanyak $1,25 \%$ mahasiswa masih belum cukup memunculkan kreatifitasnya. Hal ini disebabkan mahasiswa yang tertutupi oleh teman kelompoknya. Adanya beberapa mahasiswa yang dominan memang selalu membuat mahasiswa lain akan merasa bahwa ide yang mereka utarakan tidak akan didengarkan. Hal ini sangat riskan menjadikan mahasiswa menjadi hilang kepercayaan diri, sehingga kreatifitasnya tidak tersalurkan. Oleh karena itu, peran dosen sebagai fasilitator dan penengah harusnya bisa memberikan kesempatan yang sama kepada setiap mahasiswa untuk dapat mengutarakan idenya sehingga kreatifitas mereka dapat muncul dan bisa diterima oleh mahasiswa lain, khususnya mahasiswa yang dominan.

Poin ini memiliki hubungan dengan pernyataan nomor delapan. Pada poin kedelapan, terdapat pernyataan "Semua teman kelompok saya aktif dan menyumbangkan ide saat diberikan tugas". Pada poin ini sebanyak 95\% mahasiswa mengatakan bahwa dalam kelompok, setiap mahasiswa aktif dan dapat menyumbangkan ide, sedangkan sebanyak $5 \%$ mahasiswa mengatakan bahwa tidak semua teman kelompoknya mampu menyumbangkan ide. Hal ini sangat berkaitan dengan beberapa mahasiswa yang dominan 
dan yang tidak ingin mendengarkan pendapat temannya yang lain. Oleh karena itu, dosen sebagai fasilitator harus mampu memberikan pengertian kepada setiap mahasiswa, khususnya kepada mahasiswa yang sering mendominasi temannya bahwa setiap mahasiswa bebas memberikan ide dan kreatifitasnya dan yang lain harus memberikan apresisasi untuk ide dan kreatifitas yang telah diutarakan tersebut. Dengan begitu, setiap mahasiswa akan memperoleh keadilan dan kekurangan-kekurangan yang muncul dalam pembelajaran dengan metode Gallery Walk dapat diminimalisir.

\section{h. Dapat Bekerjasama dalam Kelompok}

Poin sepuluh berisi mengenai pernyataan bahwa "Saya mampu bekerja dalam kelompok". Berikut tabel persentasi skalanya.

Tabel 4. Persentase poin 2

\begin{tabular}{ccc}
\hline Skala & Jumlah & $\begin{array}{c}\text { Persentase } \\
(\%)\end{array}$ \\
\hline SS & 63 & 78,75 \\
S & 16 & 20 \\
C & 1 & 1,25 \\
TS & 0 & 0 \\
STS & 0 & 0 \\
\hline
\end{tabular}

Tabel di atas memperlihatkan bahwa sebanyak $78,75 \%$ mahasiswa sangat setuju, $20 \%$ setuju, dan 1,25\% cukup setuju bahwa mereka dapat bekerjasama dalam kelompok. Saat diberi tugas untuk mendiskusikan masalah yang diberian, mahasiswa akan dituntut untuk bekerjasama dengan anggota kelompoknya agar masalah yang diberikan dapat didiskusikan lalu mencari solusi bersama.

Berdasarkan uraian tersebut di atas, dapat disimpulkan bahwa sebanyak 100\% mahasiswa mengatakan bahwa metode Gallery Walk yang mereka terima membuat mereka dapa bekerjasama dalam kelompok. Sesuai dengan interview yang telah dilakukan, mahasiswa memang dapat bekerjasama dalam kelompok dengan baik, namun karena ada mahasiswa yang dominan membuat beberapa mahasiswa lain menjadi kurang percaya diri, takut untuk berbicara dan hanya menerima pendapat dari anggota kelompok lain, sehingga mereka tidak dapat mengemukakan idenya dengan jelas.

\section{Simpulan dan Saran}

Berdasarkan pembahasan dapat disimpulkan bahwa implementasi metode Gallery Walk dalam pembelajaran bahasa Jepang di jurusan Pariwisata, Politeknik Negeri Bali sangat memberikan dampak positif terhadap mahasiswa. Mahasiswa dapat menjadi pusat dari pembelajaran dan dosen menjadi fasilitator. Selain itu dampak yang timbul oleh penggunaan metode Gallery Walk bagi mahasiswa antara lain adalah: penerimaan perkuliahan jadi lebih baik, kelas menjadi lebih menyenangkan dan tidak membosankan, meningkatkan konsentrasi, membuat mahasiswa lebih aktif dalam kelas, memiliki kepercayaan diri yang tinggi, memunculkan kreatifitas, dan membuat mereka dapat bekerjasama dalam kelompok.

Hal tersebut tidak lepas dari peran serta dosen sebagai fasilitator untuk memperhatikan kegiatan yang dilakukan oleh mahasiswa, dapat melihat kekurangan mahasiswa dan meminimalisir kekurangan-kekurangan tersebut agar mereka dapat lebih baik lagi. 


\section{Daftar Pustaka}

Ambarini, N., Ariyanto, J., \& Rosyidi, A. (2013). Penerapan Pembelajaran Aktif Card Sort Disertai Mind Mapping untuk Meningkatkan Minat Belajar Peserta Didik dalam Pembelajaran Biologi di Kelas VII-E SMP Negeri 5 Surakarta. Jurnal Bio-Pedagogi. Vol. 2. No. 1 .

Chatif, M. 2012. Sekolahnya Manusia. Bandung: Kaifa Learning.

Dengo, F. 2018. Penerapan Metode Gallery dalam Meningkatkan Hasil Belajar Peserta Didik pada Pembelajaran IPA. Jurnal Manajemen Pendidikan Islam. Vol. 6. No. 1.

Gufron, M. 2011. Implementasi Metode Gallery Walk dan Small Group Discussion dalam Meningkatkan Efektifitas Pembelajaran Pendidikan Agama Islam Kelas VIII E di SMP Negeri 1 Banyuanyar Probolinggo. Skripsi. Malang: Universitas Islam Negeri Maulana Malik Ibrahim.

Kusyairy, U. 2014. Psikologi Belajar Panduan Praktisi untuk Memahami Psikologi dalam Pembelajaran. Makassar: Alauddin University Press.

Manik, Y.M., Bangun, D. 2019. Pengaruh Model Pembelajaran Kooperatif Tipe Gallery Walk Terhadap Hasil Belajar Pada Pelajaran Ekonomi Kelas X di SMA NEGERI 1 Perbaungan. Equilibrium. Vol. 7. No 2.

Marteja, S. 2020. Model Pembelajaran Gallery Walk Pada Mata Pelajaran Jurnal Khusus Perusahaan Dagang Di SMAN 1 Rejang Lebong. Jurnal Promosi: Jurnal IImu Pendidikan Ekonomi UM Metro. Vol. 8. No. 1.

Marteja, S. 2020. Upaya Meningkatkan Aktivitas Dan Hasil Belajar Akuntasi Materi Jurnal Khusus Perusahaan Dagang Siswa Kelas XII IPS2 SMA Negeri 1 Rejang Lebong Tahun Pelajaran 2019/2020. Jurnal Perspektif Pendidikan. Vol. 14. No. 1.

Nur, M. 2012. Teori Pembelajaran Kognitif. Surabaya: PPS IKIP.

Rustam, dkk. 2020. Pengaruh Penerapan Metode Gallery Walk Terhadap Minat Belajar Peserta Didik Biologi. BIOMA: Jurnal Biologi dan Pembelajaran Biologi. Vol. 5. No. 1.

Satori, D., \& Komariah, A. 2013. Metodologi Penelitian Kualitatif. Bandung: Alfabeta.

Setiawan, W. Nurasiah, H. 2018. Galery Walk Dalam Aktivitas Belajar: Penelitian Tindakan Kelas Di Madrasah Ibtidaiyah. Al-Aulad: Journal of Islamic Primary Education. Vol. 1. No. 1.

Silberman, M. 2015. Active Learning 101 Cara Belajar Siswa Aktif Edisi Revisi. Bandung: Nuansa Cendikia.

Sugiyono. 2017. Metode Penelitian Kuantitatif, Kualitatif, $R \& D$. Bandung: CV Alfabeta.

Sugiyono. 2018. Metode Penelitian Kombinasi (Mixed Methods). Bandung: CV Alfabeta. 